\title{
ANALISIS DAN DESAIN SISTEM PENILAIAN DAUR HIDUP AYAM POTONG BERBASIS DIGITAL BUSINESS ECOSYSTEM
}

\section{ANALYSIS AND DESIGN OF LIFE CYCLE ASSESSMENT SYSTEM OF CHICKEN MEAT BASED ON DIGITAL BUSINESS ECOSYSTEM}

\author{
Silmi Azmi ${ }^{*}$, Taufik Djatna, Suprihatin, Nastiti Siswi Indrasti \\ Departemen Teknik Industri Pertanian, Fakultas Teknologi Pertanian, Institut Pertanian Bogor \\ Kampus IPB Dramaga, Jl. Raya Dramaga, Bogor 16680, Indonesia \\ E-mail: $\underline{\text { silmiazmiazmi@apps.ipb.ac.id }}$
}

Makalah: Diterima 30 Desember 2020; Diperbaiki 13 Juni 2021; Disetujui 30 Juni 2021

\begin{abstract}
Chicken meat agroindustry is one of the industries that produce unmeasured and unmonitored environmental impacts. These problems are a challenge for the industry to analyze how to measure and monitor environmental impacts. So, it is necessary to create a system that can measure and monitor environmental impacts through the Life Cycle Assessment (LCA) method. The development of system design based on the Digital Business Ecosystem (DBE) can facilitate interaction between the stakeholders involved. This study aimed to analyse system components, system modeling, and develop an LCA system design of chicken meat. The system design model was built by UML (Unified Modeling Language). The system design was developed using an Artificial Neural Network (ANN) method to predict the impact of greenhouse gas emissions and the Ordinary Least Squares (OLS) method to determine the most significant contributor. The study's results showed that this system produceed a model that can predict the impact of greenhouse gas emissions by $96.22 \%$ of the actual value, and feed was the most significant contributor. Recommendations for reducing greenhouse gas emissions were increasing feed efficiency, installing an inverter on an ammonia compressor, using environmentally friendly fuels, and utilizing litter and manure as organic fertilizer accompanied by better manure storage management.
\end{abstract}

Keywords: artificial neural network, chicken meat, ordinary least square, life cycle assessment system

\begin{abstract}
ABSTRAK
Agroindustri ayam potong merupakan salah satu industri yang menghasilkan dampak lingkungan yang tidak terukur dan tidak terpantau. Permasalahan tersebut menjadi tantangan bagi industri untuk menganalisis bagaimana cara mengukur dan memantau dampak lingkungan. Sehingga, perlu membuat sebuah sistem yang dapat mengukur dan memantau dampak lingkungan melalui metode Life Cycle Assessment (LCA). Pengembangan desain sistem penilaian daur hidup ayam potong berbasis Digital Business Ecosystem (DBE) dapat mempermudah interaksi antara stakeholder yang terlibat. Penelitian ini bertujuan untuk menganalisis komponen sistem, pemodelan sistem, serta mengembangkan desain sistem penilaian daur hidup ayam potong. Model desain sistem dibangun oleh UML (Unified Modeling Language). Desain sistem dikembangkan menggunakan metode Artificial Neural Network (ANN) untuk memprediksi dampak lingkungan emisi gas rumah kaca dan Ordinary Least Square (OLS) untuk menentukan kontributor terbesar. Hasil penelitian menunjukkan bahwa sistem ini menghasilkan model yang dapat memprediksi dampak emisi gas rumah kaca sebesar $96,22 \%$ dari nilai aktualnya dan pakan merupakan kontributor terbesar. Rekomendasi perbaikan untuk mengurangi emisi gas rumah kaca adalah peningkatan efisiensi pakan, pemasangan inverter pada kompresor amonia, penggunaan bahan bakar ramah lingkungan, pemanfaatan limbah litter dan manure sebagai pupuk organik yang disertai dengan manajemen penyimpanan manure yang lebih baik.
\end{abstract}

Kata kunci: ayam potong, artificial neural network, ordinary least square, sistem penilaian daur hidup

\section{PENDAHULUAN}

Agroindustri ayam ras pedaging di Indonesia berkembang dengan sangat pesat. Tingginya konsumsi daging ayam di Indonesia diiringi dengan peningkatan produksi ayam ras pedaging. Produksi ayam ras pedaging pada tahun 2019 mencapai 3,49 juta ton, meningkat 2,64\% dibandingkan tahun sebelumnya (BPS, 2019). Proses budidaya ayam ras pedaging, transportasi serta produksi ayam potong memerlukan input berupa sumber daya selama pelaksanaan tahapan proses tersebut. Penggunaan sumber daya tersebut akan menghasilkan limbah serta emisi yang berpotensi menghasilkan dampak terhadap lingkungan.

Agroindustri ayam ras pedaging merupakan salah satu industri yang berkontribusi terhadap kerusakan lingkungan, diantaranya emisi gas rumah kaca (Suffian et al., 2018). Lima et al. (2019) menyatakan bahwa proses produksi ayam ras pedaging di peternakan menyumbang emisi gas rumah kaca karena manajemen manure sebagai kontributor terbesar dalam menghasilkan emisi gas metana $\left(\mathrm{CH}_{4}\right)$ dan dinitrogen oksida $\left(\mathrm{N}_{2} \mathrm{O}\right)$. 
Sedangkan menurut Skunca et al. (2018), konsumsi pakan dan litter di peternakan ayam serta penggunaan energi di pabrik pengolahan daging ayam berkontribusi tinggi dalam menghasilkan emisi gas rumah kaca. Kegiatan produksi di rumah pemotongan ayam (RPA) juga menghasilkan limbah baik limbah cair, padat maupun gas yang juga berkontribusi terhadap kerusakan lingkungan. Aziz et al. (2018) menyatakan bahwa limbah cair rumah pemotongan ayam memiliki konsentrasi bahan organik yang tinggi seperti kadar BOD (Biological Oxygen Demand), COD (Chemical Oxygen Demand), TSS (Total Suspended Solid), minyak lemak, nitrogen dan fosfor. Bahan organik sebagai pencemar utama ini berasal dari darah, lemak, protein terlarut dan material padatan. Pembuangan air limbah dengan kandungan nutrien yang tinggi ke perairan dapat mencemari air, mengancam ekosistem akuatik serta menimbulkan eutrofikasi. Pencemaran kualitas air juga dapat menyebabkan terjadinya penurunan kualitas kesehatan masyarakat sekitar. Selain itu, limbah padat bulu ayam dapat menimbulkan kerusakan lingkungan jika tidak ditangani dengan benar. Limbah bulu ayam yang berserakan dapat menjadi sumber penyebaran penyakit dan menimbulkan bau tidak sedap (Anbu et al., 2004). Limbah bulu ayam juga dapat mengakibatkan penurunan kualitas tanah karena sangat sulit untuk terdegradasi. Hal ini dikarenakan sebagian proteinnya berupa keratin sehingga resisten terhadap degradasi (Joshi et al., 2007).

Dampak lingkungan yang dihasilkan di sepanjang siklus hidup ayam potong tidak terukur dan tidak terpantau. Untuk mengatasi permasalahan tersebut, diperlukan sebuah sistem yang dapat mengukur dan memantau dampak lingkungan melalui pendekatan Life Cycle Assessment (LCA). Berdasarkan SNI ISO 14040:2016, Life Cycle Assessment (LCA) adalah salah satu metode pengelolaan lingkungan dalam menganalisis dan mengukur dampak lingkungan di sepanjang daur hidup produk yang dimulai dari tahap pengambilan material, produksi, distribusi, penggunaan produk hingga pembuangan akhir (BSN, 2016). Penelitian tentang evaluasi dampak lingkungan dengan pendekatan LCA di agroindustri ayam ras pedaging sudah banyak dilakukan, baik di sepanjang kegiatan budidaya, transportasi dan produksi ayam potong (Leinonen et al., 2012; González-García et al., 2014; Kalhor et al., 2016; Cesari et al., 2017; Wiedemann et al., 2017; López-Andrés et al., 2018) maupun disertai proses distribusi, penggunaan oleh konsumen hingga pembuangan akhir (Skunca et al., 2018). Bahkan penelitian tentang pengukuran kinerja rantai pasok dan nilai tambah hijau dengan mempertimbangkan aspek lingkungan melalui metode LCA pada agroindustri ayam ras pedaging telah dilakukan oleh Nurhayati et al. (2016). Akan tetapi, penelitian tentang mendesain sistem yang dapat mengevaluasi dampak lingkungan pada agroindustri ayam ras pedaging masih terbatas.

Penilaian daur hidup ayam potong melibatkan beberapa stakeholder yaitu manajemen, divisi lingkungan, peternakan ayam, rumah pemotongan ayam dan laboratorium uji. Untuk mempermudah interaksi antara stakeholder, maka perlu dikembangkan desain sistem penilaian daur hidup ayam potong berbasis Digital Business Ecosystem (DBE) agar dihasilkan sistem yang terintegrasi dan memudahkan dalam mencapai tujuan. Djatna (2020) menyatakan bahwa DBE merupakan sistem interaksi bisnis yang terjadi secara peer to peer (P2P) antara aktor-aktor pada ekosistem bisnis yang saling terkait pada lingkungan digital yang dihubungkan menggunakan suatu jaringan infrastruktur digital. Identifikasi komponen sistem dilakukan sebelum mengembangkan desain sistem. Model desain sistem dibangun oleh UML (Unified Modeling Language). Metode yang digunakan dalam mengembangkan desain sistem ini adalah Artificial Neural Network (ANN) untuk memprediksi dampak lingkungan emisi gas rumah kaca dan Ordinary Least Square (OLS) untuk menentukan hotspot atau kontributor terbesar terhadap emisi gas rumah kaca. Berdasarkan hasil prediksi dampak lingkungan dan hotspot yang telah diketahui, maka dapat ditentukan rekomendasi perbaikan untuk menurunkan dampak lingkungan.

Tujuan penelitian ini adalah untuk menganalisis komponen sistem, pemodelan sistem, serta mengembangkan desain sistem penilaian daur hidup ayam potong. Penelitian ini akan menghasilkan sebuah sistem penilaian daur hidup ayam potong yang lebih sederhana, cepat dan dapat terpantau secara real time melalui platform digital. Penilaian daur hidup ayam potong dapat memberikan manfaat bagi perusahaan dalam pengelolaan lingkungan. Sistem ini dibuat untuk perusahaan yang terintegrasi dari peternakan ayam ras pedaging hingga rumah pemotongan ayam (RPA). Sistem ini dapat memberikan gambaran mengenai dampak lingkungan yang dihasilkan di sepanjang daur hidup produk, yang dalam penelitian ini terbatas pada kegiatan budidaya, transportasi dan produksi ayam potong. Hasil dari prediksi dampak lingkungan serta rekomendasi perbaikan diharapkan bisa menjadi acuan dalam mengurangi dampak lingkungan di perusahaan.

\section{METODE PENELITIAN}

\section{Kerangka Penelitian}

Metode dalam penelitian ini didasarkan pada masing-masing tujuan yang ingin dicapai, yaitu menganalisis komponen sistem, pemodelan sistem dan mendesain sistem penilaian daur hidup ayam potong. Gambar 1 menunjukkan kerangka penelitian dalam mencapai masing-masing tujuan tersebut. 


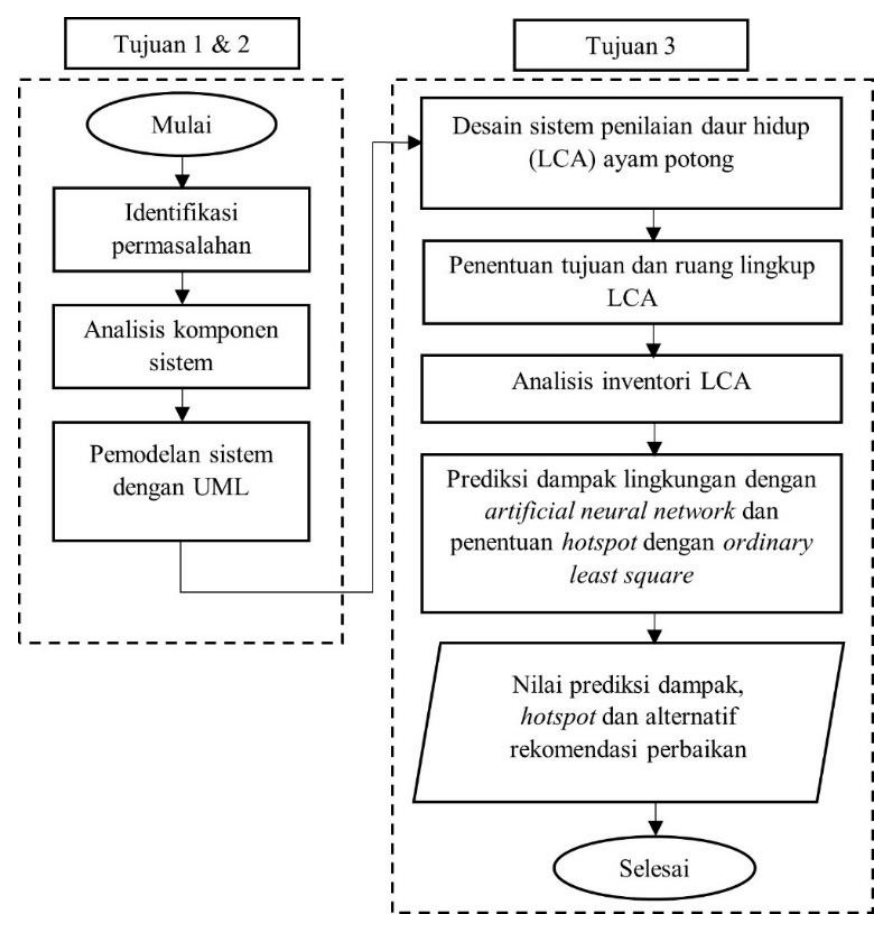

Gambar 1. Kerangka penelitian

\section{Analisis Komponen Sistem}

Analisis komponen sistem dilakukan untuk mengidentifikasi komponen-komponen atau atributatribut pembangun sistem yang meliputi input serta output yang diinginkan dan tidak diinginkan, pemangku kepentingan, peran, sumber daya, kontrol internal, peluang, ancaman, batasan operasional, serta timbal balik dalam bentuk self interaction. Atributatribut ini perlu diperhatikan ketika akan mendesain serta mengembangkan sistem karena akan berdampak pada kinerja sistem (Djatna, 2020).

\section{Pemodelan Sistem dengan Unified Modeling Language (UML)}

Unified Modeling Language (UML) digunakan dalam pemodelan sistem dengan bantuan software PowerDesigner versi 16.5.03982. Djatna (2020) menyatakan bahwa UML digunakan untuk menyimpan, menspesifikasikan, serta membangun suatu sistem. Pemodelan sistem penilaian daur hidup ayam potong menggunakan UML berupa use case serta BPMN (Business Process Model Notation). Menurut Djatna (2020), use case mengilustrasikan bagaimana hubungan pengguna dan aktivitas. Sedangkan BPMN merupakan suatu cara untuk merepresentasikan aliran bisnis dengan serangkaian notasi grafis yang menjadi bentuk sederhana atau pemodelan bisnis agar lebih mudah untuk dimengerti.

\section{Desain Sistem Penilaian Daur Hidup}

Formulasi dalam mendesain sistem ini mengacu pada empat tahapan LCA menurut BSN (2016) dalam SNI ISO 14040:2006, yaitu menentukan tujuan dan ruang lingkup, analisis inventori, analisis dampak lingkungan dengan metode
Artificial Neural Network (ANN) untuk memprediksi dampak lingkungan emisi gas rumah kaca dan interpretasi hasil dengan metode Ordinary Least Square (OLS) untuk menentukan hotspot serta penentuan alternatif rekomendasi perbaikan dalam penurunan dampak lingkungan. Pengolahan data menggunakan software R Studio versi 3.6.2.

\section{Penentuan Tujuan dan Ruang Lingkup}

Pada tahap ini ditentukan tujuan dari kajian LCA, batasan sistem serta kategori dampak yang akan dikaji (BSN, 2016). Tujuan dari kajian LCA ayam potong dalam sistem ini adalah untuk mengevaluasi dampak lingkungan ayam potong dalam ruang lingkup cradle-to-gate, menentukan hotspot dan rekomendasi perbaikan. Batasan sistem LCA ayam potong seperti yang disajikan pada Gambar 2 adalah cradle-to-gate, yaitu mulai dari proses budidaya ayam ras pedaging, transportasi, dan proses produksi ayam potong. Kategori dampak lingkungan yang dikaji berupa dampak emisi gas rumah kaca. Emisi yang menyebabkan gas rumah kaca di agroindustri ayam potong adalah karbon dioksida $\left(\mathrm{CO}_{2}\right)$, metana $\left(\mathrm{CH}_{4}\right)$, dan dinitrogen oksida $\left(\mathrm{N}_{2} \mathrm{O}\right)$. Emisi $\mathrm{CO}_{2}$ berasal dari penggunaan bahan bakar diesel, LPG, listrik, bahan kemasan plastik dan bahan pembersih. Emisi $\mathrm{CH}_{4}$ berasal dari penggunaan bahan bakar diesel, LPG, limbah cair dan limbah padat. Sedangkan, emisi $\mathrm{N}_{2} \mathrm{O}$ berasal dari penggunaan bahan bakar diesel, LPG dan litter. Pada analisis dampak terhadap emisi gas rumah kaca, hasil perhitungan emisi $\mathrm{CO}_{2}, \mathrm{CH}_{4}$, dan $\mathrm{N}_{2} \mathrm{O}$ selanjutnya dikonversi menjadi karbon dioksida ekuivalen $\left(\mathrm{CO}_{2}-\right.$ eq) menggunakan nilai konversi berdasarkan IPCC (2007). 


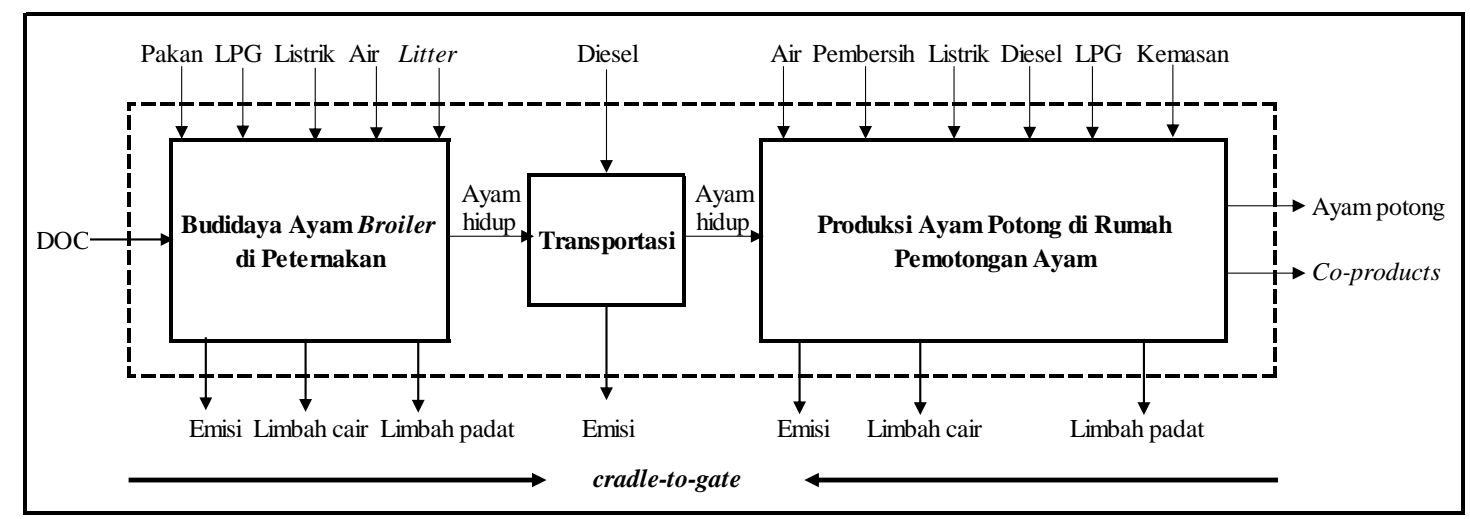

Gambar 2. Batasan sistem penilaian daur hidup ayam potong (cradle-to-gate)

Tabel 1. Inventori data agroindustri ayam potong

\begin{tabular}{llll}
\hline Inventori & \multicolumn{3}{c}{ Tahapan Kegiatan } \\
\cline { 2 - 4 } Data & Budidaya & Transportasi & Produksi \\
\hline Input & Day old chicks (DOC) & Diesel & Ayam hidup \\
& Air & & Air \\
& Pakan & Sodium hydroxide \\
& Litter & Sodium hypochlorite \\
& Listrik & Listrik \\
& LPG & Diesel \\
& & LPG \\
& & Bahan kemasan \\
\hline Output & Ayam hidup & Ayam potong \\
& Limbah cair & Limbah cair \\
& Limbah padat & Limbah padat \\
\hline
\end{tabular}

\section{Analisis Inventori}

Analisis inventori dilakukan untuk mengidentifikasi aliran input (bahan baku, bahan tambahan dan energi) dan output (produk, produk samping, limbah dan emisi) sepanjang siklus hidup produk (BSN, 2016). Inventori data dalam sistem ini berupa identifikasi input dan output pada proses budidaya ayam ras pedaging, transportasi, dan proses produksi ayam potong. Data input dan output yang dijadikan sebagai acuan data inventori berasal dari data hipotetik yang komponennya mengacu pada penelitian Skunca et al. (2018). Inventori data pada tahap kegiatan budidaya, transportasi dan produksi disajikan pada Tabel 1. Berdasarkan data sekunder yang diperoleh dari penelitian Skunca et al. (2018), input bahan bakar diesel pada proses transportasi dihitung sebagai input pada proses budidaya.

Inventori data tersebut selanjutnya dikelompokkan menjadi tujuh variabel prediktor, yaitu pakan peternakan, energi peternakan, limbah peternakan, energi RPA, limbah RPA, bahan kemasan RPA dan bahan pembersih RPA dengan satu variabel target yaitu emisi $\mathrm{CO}_{2}$-eq. Data-data tersebut kemudian diproses dengan menggunakan Microsoft Excel dengan perintah "randbetween" untuk menghasilkan 100 data untuk masing-masing variabel.
Analisis Dampak Lingkungan dengan Artificial Neural Network (ANN)

Russell dan Norvig (2010) menyatakan bahwa Artificial Neural Network (ANN) merupakan model komputasi berdasarkan prinsip kerja dari jaringan saraf manusia. ANN dapat digunakan untuk masalah klasifikasi atau prediksi numerik (Han et al., 2012). Dalam sistem ini, metode ANN digunakan untuk memprediksi dampak emisi gas rumah kaca. Back propagation merupakan salah satu algoritma ANN yang akan memproses data latih dengan membandingkan hasil prediksi dari jaringan dengan nilai target aktual. ANN back propagation meliputi input layer, hidden layer, serta output layer. Setiap lapisan dibentuk oleh sejumlah node atau neuron. Node lapisan atas dan bawah dihubungkan dengan pembobot $w_{i j}$ dan $w_{j}$ dimana $i=1,2, \ldots, n$ dan $j=1$, $2, \ldots, m$, ( $n$ : banyaknya lapisan neuron input; $m$ : jumlah lapisan neuron tersembunyi) (Siang, 2005). Pada ANN back propagation dengan $n$ neuron input, $m$ neuron tersembunyi, dan satu neuron output, output dari semua lapisan tersembunyi dihitung dengan formulasi sebagai berikut (Zhang et al., 2013):

$n e t_{j}=\sum w_{i j} x_{i}(i=0,1, \ldots, n ; j=0,1, \ldots, m) \ldots \ldots \ldots \ldots$ 
$y_{i}=f\left(\right.$ net $\left._{j}\right)(j=1,2, \ldots, m)$

Pada formula di atas, net $t_{j}$ merupakan nilai aktivasi dari node ke-j, $\omega_{i j}$ bobot dari node input ke-i dan node tersembunyi ke-j, $x_{i}$ input ke-i, $y_{j}$ output node ke-j pada hidden layer, dan $f$ fungsi aktivasi dari suatu node yang biasanya merupakan fungsi sigmoid (Zhang et al., 2013).

$f(x)=\frac{1}{1+\exp (-x)}$

Output dari seluruh neuron diekspresikan dengan:

$0=f_{0}\left(\sum w_{j} y_{j}\right)(j=0,1, \ldots, m)$

Pada formula output, $f_{0}$ merupakan fungsi aktivasi, $\omega_{j}$ pembobot pada hubungan node ke-j pada hidden layer dengan node ouput, dan $y_{j}$ output dari node ke-j pada hidden layer (Zhang et al., 2013).

\section{Interpretasi Hasil dengan Ordinary Least Square (OLS)}

Metode Ordinary Least Square (OLS) digunakan dalam mengestimasi garis regresi melalui pengurangan jumlah kuadrat galat observasi pada garis (Kuncoro, 2014). Dengan menggunakan metode OLS, penduga parameter regresi dapat dihitung. OLS berfungsi untuk mengetahui bagaimana pengaruh dari independent variable $(x)$ pada dependent variable $(y)$. Analisis regresi linear berganda dengan metode OLS pada sistem ini bertujuan untuk menentukan kontributor terbesar terhadap emisi gas rumah kaca. Djatna (2020) menyatakan bahwa regresi linear berganda merupakan pemodelan regresi yang berdasarkan lebih dari satu variabel prediktor. Berikut ini merupakan formulasi dari regresi linear berganda:

$\hat{y}=\beta_{0}+\beta_{1} x_{1}+\beta_{2} x_{2}+\ldots+\beta_{n} x_{n}$

Pada formulasi tersebut, $\beta$ adalah beta coefficient $\beta_{l}$, $\beta_{2}, \ldots, \beta_{n}, \hat{y}$ adalah target variabel, dan $x$ adalah variabel prediktor $x_{1}, x_{2}, \ldots, x_{n}$ (Djatna, 2020).

\section{HASIL DAN PEMBAHASAN}

\section{Analisis Komponen Sistem}

Sistem penilaian daur hidup ayam potong berbasis DBE adalah elemen yang terintegrasi melalui input berupa data produksi, limbah dan emisi yang diproses dalam tahapan proses LCA menurut BSN (2016), yaitu penentuan tujuan dan ruang lingkup, analisis inventori, analisis dampak lingkungan dengan metode ANN untuk memprediksi dampak emisi gas rumah kaca, serta interpretasi hasil dengan metode OLS untuk menentukan hotspot, sehingga diperoleh output berupa hasil nilai prediksi emisi $\mathrm{CO}_{2}$-eq yang mendekati nilai aktual serta diketahui hotspot yang tepat sebagai dasar perumusan rekomendasi perbaikan. Gambar 3 menunjukkan komponen pembangun sistem penilaian daur hidup ayam potong.

Konsep DBE pada sistem penilaian daur hidup ayam potong yang mengacu pada Djatna (2020), merupakan sistem interaksi bisnis yang terjadi secara peer to peer $(\mathrm{P} 2 \mathrm{P})$ antara aktor-aktor yang terdiri dari manajemen, divisi lingkungan, peternakan ayam, rumah pemotongan ayam dan laboratorium uji, yang saling terikat dan berinteraksi pada lingkungan digital yang dihubungkan menggunakan suatu jaringan information and communication technology (ICT) sehingga aktor-aktor pada lingkungan ekosistem tersebut dapat saling berkomunikasi dan bertukar informasi menggunakan infrastruktur digital seperti informasi data produksi, limbah dan emisi, data hasil analisis dampak lingkungan serta rekomendasi perbaikan.

\section{Pemodelan Sistem dengan Unified Modeling Language (UML) \\ Use Case Diagram}

Use case mengilustrasikan interaksi pengguna atau bagaimana hubungan aktor dengan aktivitas (Djatna, 2020). Dalam sistem ini terjadi interaksi antara lima aktor yaitu manajemen, divisi lingkungan, peternakan ayam, rumah pemotongan ayam dan laboratorium uji, dengan lima tahapan proses bisnis seperti pada Gambar 4. Dengan konsep DBE, interaksi antara aktor berlangsung secara digital sehingga lebih cepat, mudah dan terpantau dalam sistem penilaian daur hidup ayam potong.

\section{BPMN 2.0}

Business Process Model Notation (BPMN) pada sistem ini menggambarkan interaksi antara stakeholder yang terdiri dari manajemen, divisi lingkungan, peternakan ayam, rumah pemotongan ayam dan laboratorium uji, dalam aliran proses yang jelas. Manajemen akan memberikan instruksi kepada divisi lingkungan untuk melakukan penilaian daur hidup. Setelah menerima instruksi, divisi lingkungan akan mulai menentukan tujuan dan ruang lingkup sebagai tahap pertama dari penilaian daur hidup. Untuk melakukan analisis inventori sebagai tahap kedua, peternakan ayam dan rumah pemotongan ayam akan memasukkan data produksi ke dalam sistem atau database inventori yang akan diterima oleh divisi lingkungan. Divisi lingkungan selanjutnya akan mengajukan permohonan pengujian limbah ke laboratorium uji. Hasil uji limbah tersebut akan diberikan ke divisi lingkungan sebagai data tambahan untuk menghitung emisi. Hasil analisis inventori akan dijadikan sebagai dasar untuk melakukan analisis dampak lingkungan yang dimulai dengan pemilihan kategori dampak emisi gas rumah kaca, melakukan karakterisasi, klasifikasi dan memprediksi nilai dampak emisi gas rumah kaca.

Hasilnya berupa prediksi nilai $\mathrm{CO}_{2}$-eq yang akan dijadikan sebagai dasar pada tahap interpretasi hasil. Pada tahap ini akan dilakukan identifikasi isu 
penting, evaluasi dan penentuan hotspot. Hasil prediksi nilai $\mathrm{CO}_{2}$-eq dan hotspot yang telah diketahui akan dijadikan sebagai dasar perumusan rekomendasi perbaikan yang selanjutnya akan diberikan kepada manajemen sebagai akhir dari penilaian daur hidup ayam potong. BPMN sistem penilaian daur hidup ayam potong disajikan pada Gambar 5. Verifikasi BPMN menunjukkan bahwa tidak terdapat error yang ditemukan dalam model.

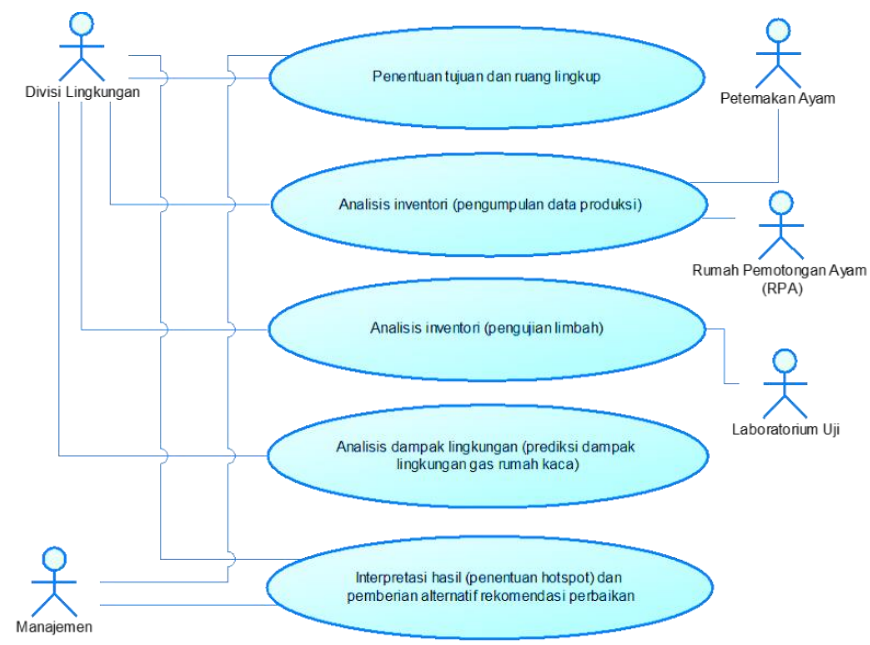

Gambar 4. Use case diagram sistem penilaian daur hidup ayam potong

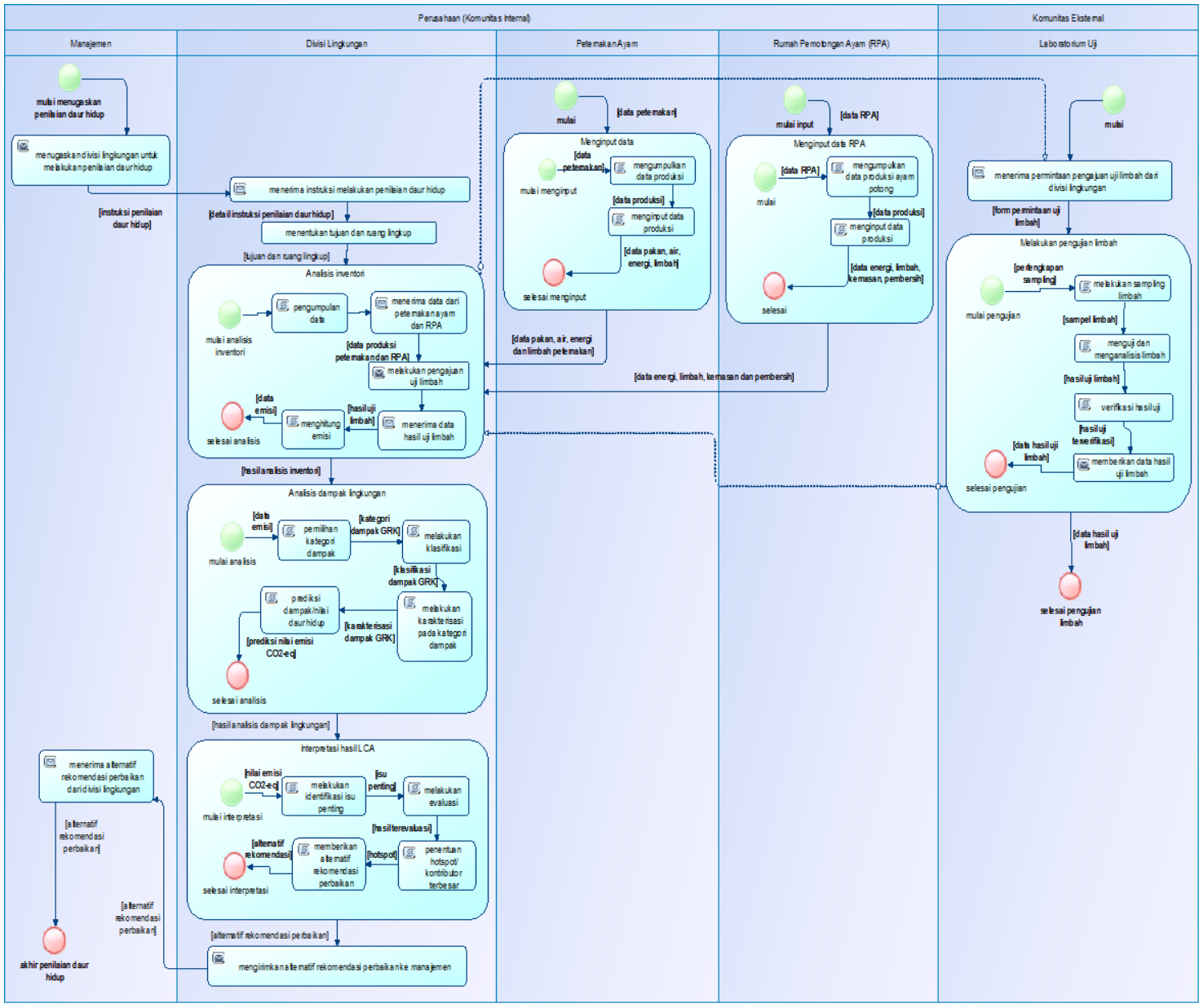

Gambar 5. BPMN sistem penilaian daur hidup ayam potong 


\section{Desain Sistem Penilaian Daur Hidup}

Analisis Dampak Lingkungan dengan Artificial Neural Network (ANN)

Analisis dampak lingkungan dilakukan untuk mengkuantifikasi data inventori menjadi potensi dampak lingkungan (Klopffer dan Grahl, 2014). Dampak lingkungan yang dianalisis dalam sistem ini yaitu potensi emisi gas rumah kaca. Analisis dampak lingkungan dilakukan untuk mengevaluasi dampak emisi gas rumah kaca yang dihasilkan berdasarkan data yang telah dimasukkan ke dalam sistem dengan menggunakan metode ANN.

Dataset yang digunakan berupa data emisi yang terdiri dari 101 baris data dan 8 kolom data. Untuk memprediksi dampak emisi gas rumah kaca, maka target variabelnya adalah emisi $\mathrm{CO}_{2}$-eq. Variabel target emisi $\mathrm{CO}_{2}$-eq akan diprediksi oleh 7 variabel prediktor seperti yang terlihat pada Tabel 2 berupa desain variabel model ANN untuk memprediksi dampak emisi gas rumah kaca.

Berdasarkan hasil pengolahan data dengan menggunakan software R studio versi 3.6.2, diperoleh rumus empiris terbaik dari hasil pemodelan ANN dengan konfigurasi ANN 7-9-1 (tujuh variabel input, sembilan neuron pada satu hidden layer serta satu output) yang dapat dilihat pada Gambar 6. Model ini terdiri dari 7 variabel yang menjadi input, yaitu emisi pakan peternakan, emisi energi peternakan, emisi limbah peternakan, emisi energi RPA, emisi limbah RPA, emisi kemasan RPA dan emisi pembersih RPA. Pada model tersebut hanya memiliki satu hidden layer yang disebut dengan single layer dan mempunyai 9 node atau neuron. Jumlah neuron ini merupakan jumlah neuron yang menghasilkan model terbaik dengan nilai error terkecil. Pada model ini hanya memiliki 1 output yaitu emisi $\mathrm{CO}_{2}$-eq.

Menurut Zhang et al. (2013), loss yang dihasilkan saat training pada network disebut error. Model ini menghasilkan error sebesar 0,217564, yang artinya rata-rata nilai prediksi melenceng sebesar 0,217564 dari nilai aktualnya. Tabel 3 menunjukkan perbandingan nilai error dari masingmasing model dengan berbagai perbedaan jumlah neuron.

Tabel 2. Desain variabel model ANN untuk memprediksi emisi gas rumah kaca

\begin{tabular}{clcc}
\hline Variabel & \multicolumn{1}{c}{ Definisi } & Jenis Data & Range Data \\
\hline$x_{1}$ & Emisi pakan peternakan & Numerik & $1,602-2,211 \mathrm{~kg}$ \\
$x_{2}$ & Emisi energi peternakan & Numerik & $0,099-0,136 \mathrm{~kg}$ \\
$x_{3}$ & Emisi limbah peternakan & Numerik & $0,008-0,011 \mathrm{~kg}$ \\
$x_{4}$ & Emisi energi RPA & Numerik & $0,175-0,395 \mathrm{~kg}$ \\
$x_{5}$ & Emisi limbah RPA & Numerik & $0,100-0,225 \mathrm{~kg}$ \\
$x_{6}$ & Emisi kemasan RPA & Numerik & $0,002-0,004 \mathrm{~kg}$ \\
$x_{7}$ & Emisi pembersih RPA & Numerik & $0,002-0,004 \mathrm{~kg}$ \\
$y$ & Emisi CO $\mathrm{CO}_{2}$-eq & Numerik & $1,99-2,99 \mathrm{~kg} \mathrm{CO} 2$-eq \\
\hline
\end{tabular}

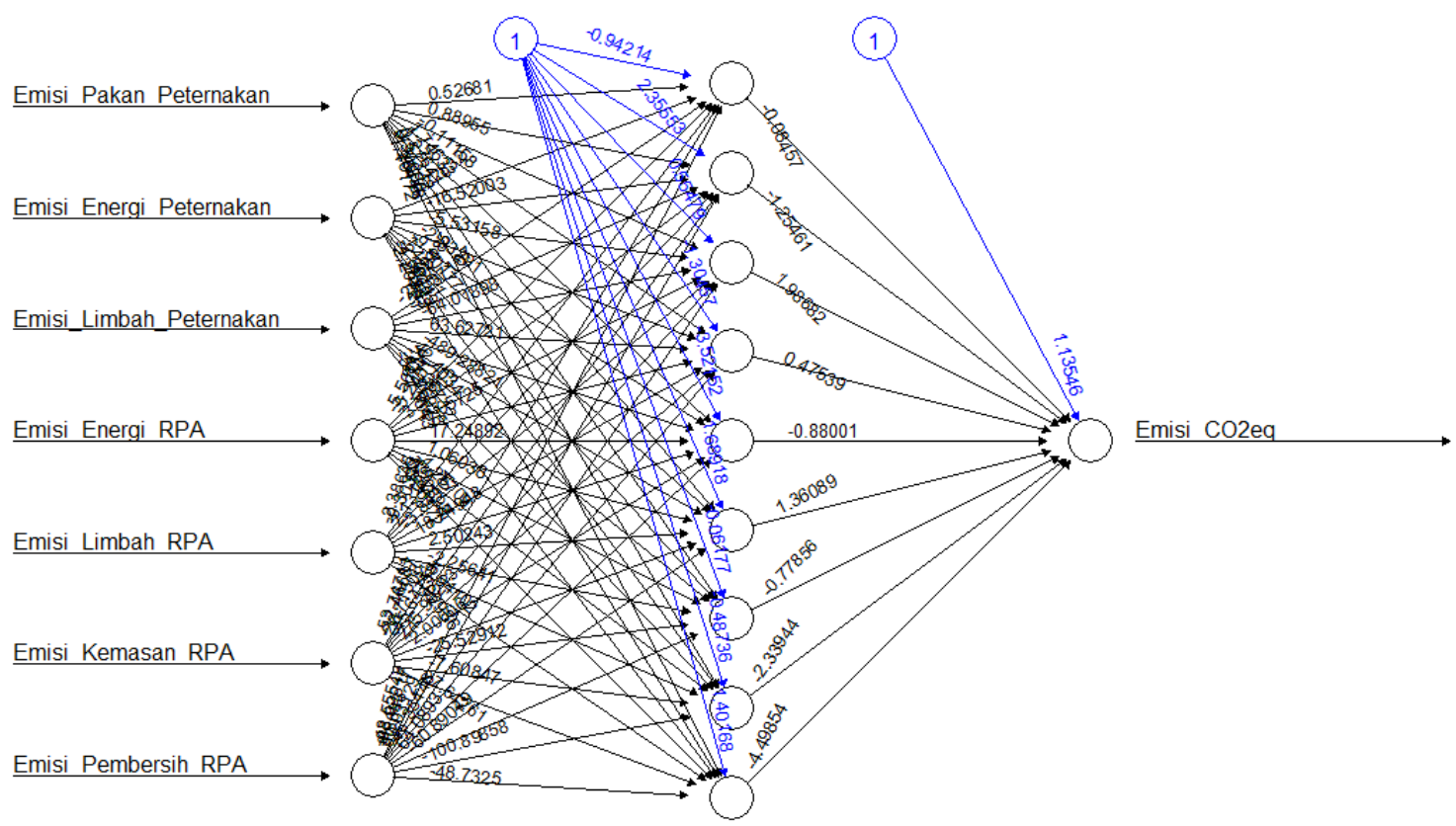

Error: 0.217564 Stens: 5571 
Gambar 6. Model terbaik dengan konfigurasi ANN 7-9-1

Tabel 3. Perbandingan error pada masing-masing model

\begin{tabular}{ccc}
\hline Hidden Layer & $\begin{array}{c}\text { Jumlah } \\
\text { Neuron }\end{array}$ & Error \\
\hline $\mathbf{1}$ & $\mathbf{1}$ & 0,317659 \\
$\mathbf{1}$ & $\mathbf{3}$ & 0,29804 \\
$\mathbf{1}$ & 5 & 0,284272 \\
$\mathbf{1}$ & 7 & 0,25399 \\
$\mathbf{1}$ & 9 & 0,217564 \\
\hline
\end{tabular}

Setelah mengetahui bentuk plot ANN, maka selanjutnya melakukan prediksi model. Model diuji menggunakan data uji dari dataset dengan menggunakan fungsi compute dan menghasilkan nilai prediksi dari data uji. Output dari hasil prediksi model yaitu berupa perbandingan nilai prediksi dengan nilai aktual emisi $\mathrm{CO}_{2}$-eq. Pada model konfigurasi ANN 7 9-1 menunjukkan bahwa pada nilai aktual emisi $\mathrm{CO}_{2-}$ eq sebesar 1,0000000 maka prediksinya adalah 0,9622257 , yang artinya model dapat memprediksi emisi $\mathrm{CO}_{2}$-eq sebesar 96,22\% dari nilai aktualnya. Tabel 4 memperlihatkan perbandingan nilai prediksi dengan nilai aktual emisi $\mathrm{CO}_{2}$-eq pada model.

\section{Interpretasi Hasil dengan Ordinary Least Square (OLS)}

Setelah melakukan prediksi dampak emisi gas rumah kaca, selanjutnya dilakukan analisis menggunakan OLS untuk menentukan kontributor terbesar atau variabel prediktor $(x)$ yang paling mempengaruhi variabel target $(y)$. Variabel target emisi $\mathrm{CO}_{2}$-eq akan diprediksi oleh 7 variabel prediktor yaitu pakan peternakan $\left(x_{1}\right)$, penggunaan energi peternakan $\left(x_{2}\right)$, limbah peternakan $\left(x_{3}\right)$, penggunaan energi RPA $\left(x_{4}\right)$, limbah RPA $\left(x_{5}\right)$, bahan kemasan RPA $\left(x_{6}\right)$ dan bahan pembersih RPA $\left(x_{7}\right)$. Berdasarkan hasil pengolahan data dengan menggunakan software R studio versi 3.6.2, diperoleh model sebagai berikut:

$$
\begin{aligned}
Y= & 0,18554+0,66102 x_{1}+1,56019 x_{2}+49,32806 x_{3} \\
& +1,34260 x_{4}-0,05441 x_{5}-20,65049 x_{6}+ \\
& 44,02029 x_{7}
\end{aligned}
$$

Interpretasi dari model yang dihasilkan dapat dilihat berdasarkan nilai koefisien, yaitu ketika semua prediktor bernilai 0 maka emisi $\mathrm{CO}_{2}$-eq sebesar 0,18554 . Ketika pakan peternakan naik $1 \mathrm{~kg}$ maka pakan peternakan akan berkontribusi positif sebesar 0,66102 dan ketika limbah RPA naik $1 \mathrm{~kg}$ maka limbah RPA akan berkontribusi negatif sebesar 0,05441, begitupun dengan variabel prediktor lainnya. Selain nilai koefisien, nilai p-value akan menunjukkan bagaimana pengaruh variabel prediktor terhadap variabel target. Besarnya $p$-value yang diperoleh adalah kurang dari 2,2 x $10^{-16}$, yang artinya variabel target emisi $\mathrm{CO}_{2}$-eq dipengaruhi secara signifikan oleh variabel prediktor. Sedangkan, adjusted $R$-square yang diperoleh adalah 0,8797 yang berarti bahwa emisi $\mathrm{CO}_{2}$-eq dapat dijelaskan sebesar $87,97 \%$ oleh prediktor-prediktor dalam model.

Menurut Djatna (2020), RMSE (Root Mean Square Error) adalah salah satu metrik paling banyak digunakan untuk mengevaluasi model kesalahan kontinyu. Berdasarkan hasil pemodelan diperoleh nilai RMSE sebesar 0,0747004 yang artinya rata-rata nilai prediksi melenceng sebesar 0,0747004 dari nilai aktualnya. Model tersebut kemudian dilakukan uji asumsi linearity untuk memeriksa linearitas antara variabel dengan melihat $p$-value yang bernilai kurang dari 0,05 untuk menolak $\mathrm{H}_{0}$, sehingga kesimpulannya adalah linear. Berdasarkan hasil pengujian, diperoleh kesimpulan bahwa model yang dibuat adalah linear. Untuk mengetahui korelasi antara variabel $x$ dan $y$ digunakan uji korelasi Pearson. Berdasarkan hasil uji diketahui bahwa variabel prediktor pakan peternakan, penggunaan energi RPA, dan limbah peternakan berkorelasi tinggi. Berdasarkan hasil tersebut dapat disimpulkan bahwa variabel prediktor pakan peternakan merupakan variabel yang paling berpengaruh. Sehingga dengan kata lain merupakan hotspot atau kontributor terbesar terhadap emisi $\mathrm{CO}_{2}-$ eq, dengan nilai korelasi sebesar 0,9009266, disusul oleh penggunaan energi RPA sebesar 0,8554684 dan limbah peternakan sebesar 0,8259373. Tabel 5 memperlihatkan nilai korelasi antara variabel prediktor dengan variabel target emisi $\mathrm{CO}_{2}$-eq.

Tabel 4. Perbandingan nilai prediksi dan nilai aktual emisi $\mathrm{CO}_{2}-\mathrm{eq}$

\begin{tabular}{ccc}
\hline \multirow{2}{*}{ Jumlah Neuron } & $\begin{array}{c}\text { Nilai Aktual Emisi CO} \text {-eq }(\mathbf{k g} \\
\mathbf{C O}_{2} \text {-eq) }\end{array}$ & $\begin{array}{c}\text { Nilai Prediksi Emisi CO} \text {-eq (kg } \\
\mathbf{C O}_{2} \text {-eq) }\end{array}$ \\
\hline 1 & 2,96 & 2,823285 \\
3 & 2,75 & 2,842689 \\
5 & 2,58 & 2,654299 \\
7 & 2,09 & 2,160210 \\
9 & 2,19 & 2,258611 \\
\hline
\end{tabular}


Tabel 5. Korelasi antara variabel prediktor terhadap variabel target

\begin{tabular}{clc}
\hline Variabel Prediktor & \multicolumn{1}{c}{ Definisi } & Korelasi (r) \\
\hline$x_{1}$ & Pakan peternakan & 0,9009266 \\
$x_{2}$ & Penggunaan energi peternakan & 0,8080866 \\
$x_{3}$ & Limbah peternakan & 0,8259373 \\
$x_{4}$ & Penggunaan energi RPA & 0,8554684 \\
$x_{5}$ & Limbah RPA & 0,8138485 \\
$x_{6}$ & Bahan kemasan RPA & 0,7743175 \\
$x_{7}$ & Bahan pembersih RPA & 0,7958602 \\
\hline
\end{tabular}

\section{Penentuan Rekomendasi Perbaikan}

Hasil dari studi LCA dalam sistem ini menyatakan bahwa pakan memberikan kontribusi terbesar terhadap emisi gas rumah kaca. Hal ini sesuai dengan hasil studi LCA ayam ras pedaging oleh penelitian lain yang menunjukkan bahwa pakan memberikan kontribusi tertinggi baik yang hanya mengevaluasi pada tahapan budidaya, transportasi dan produksi (Leinonen et al., 2012; González-García et al., 2014; Kalhor et al., 2016; Nurhayati et al., 2016; Cesari et al., 2017; Wiedemann et al., 2017; López-Andrés et al., 2018) maupun yang menyertakan tahapan pengolahan daging ayam, penggunaan konsumen hingga pembuangan akhir (Skunca et al., 2018).

Pakan ayam menjadi kontributor terbesar karena selain ekskresi nitrogen dari pakan yang dikonsumsi, juga karena pakan dihasilkan melalui beberapa tahapan proses, mulai dari proses produksi bahan baku pakan, transportasi bahan baku, proses produksi pakan hingga transportasi pakan ke peternakan. Semua kegiatan yang berhubungan dengan pakan tersebut bertanggung jawab atas kerusakan lingkungan. Hal ini dikarenakan pada proses tersebut dibutuhkan sumber daya seperti pupuk, pestisida, air, bahan bakar fosil, listrik, bahan pembersih, bahan kemasan dan sumber daya lain yang dapat menghasilkan limbah dan emisi yang berdampak terhadap lingkungan. Pelletier (2008) melaporkan bahwa pakan menyumbang $82 \%$ dari total emisi gas rumah kaca. Hal yang sama dengan penelitian Leinonen et al. (2012) bahwa kontribusi pakan terhadap total emisi gas rumah kaca lebih dari 70\%. Menurut penelitian González-García et al. (2014) dan López-Andrés et al. (2018), produksi bahan pakan (penggunaan bahan kimia dan energi) dan penggunaan energi pada produksi pakan merupakan proses utama yang bertanggung jawab terhadap dampak lingkungan. Tahap produksi bahan pakan (budidaya tanaman) membutuhkan input sumber daya dan energi yang sangat besar untuk proses pembukaan lahan, perawatan dan perbaikan struktur tanah, serta perawatan tanaman, yang dapat menghasilkan emisi gas rumah kaca terutama $\mathrm{CO}_{2}$.

Rekomendasi perbaikan yang berpotensi mengurangi dampak emisi gas rumah kaca dari pakan adalah dengan meningkatkan efisiensi pakan, yaitu dari segi jumlah, komposisi serta kandungan nutrisi dalam pakan yang dikonsumsi. Jumlah pakan yang dikonsumsi akan mempengaruhi limbah kotoran ayam yang dihasilkan. Konsumsi pakan yang lebih efisien dapat mengurangi jumlah kotoran ayam sehingga emisi $\mathrm{NH}_{3}, \mathrm{~N}_{2} \mathrm{O}$ dan $\mathrm{CH}_{4}$ di dalam kandang juga dapat berkurang (Leinonen et al., 2012). Dalam penelitian Kalhor et al. (2016) disebutkan bahwa terdapat perbedaan yang signifikan antara ayam ras pedaging yang dipelihara dalam kandang yang menggunakan sistem tunnel-ventilation dengan kandang konvensional. Ayam yang dihasilkan dari kandang dengan sistem tunnel-ventilation memiliki bobot yang lebih berat dan memiliki nilai Feed Conversion Ratio (FCR) yang lebih baik. Penurunan jumlah konsumsi pakan per kg ayam hidup berkaitan langsung dengan pengurangan beban lingkungan. Tallentire et al. (2017) juga menyebutkan bahwa nilai FCR yang lebih baik dapat mengurangi dampak lingkungan. Feed Conversion Ratio (FCR) merupakan banyaknya kilogram pakan yang dikonsumsi untuk menghasilkan satu kilogram bobot ayam hidup (Fadilah et al., 2006), sehingga semakin kecil nilai FCR maka semakin efisien pakan yang dikonsumsi.

Penggunaan bahan pakan khusus (aditif) pada pakan seperti enzim dan asam amino dapat meningkatkan kinerja lingkungan (Leinonen dan Kyriazakis, 2016). Formulasi pakan dengan penambahan asam amino dan enzim phytase pada penelitian Kebreab et al. (2016) mengurangi penggunaan bungkil kedelai impor dari Amerika Serikat sekitar $50 \%$ yang menyebabkan terjadinya penurunan dampak pemanasan global sebesar $44 \%$. Penelitian Giannenas et al. (2017) melaporkan bahwa penambahan protease dan substitusi bungkil kedelai dengan corn gluten meal memiliki kinerja lingkungan yang lebih baik dibandingkan standar diet ayam ras pedaging terhadap sembilan kategori dampak lingkungan termasuk pemanasan global. Pengurangan crude protein dalam pakan juga merupakan strategi yang relevan untuk mengurangi dampak pemanasan global (Leinonen dan Williams, 2015). Pengurangan crude protein dan penambahan enzim protease dalam studi Leinonen dan Williams (2015) dapat menurunkan dampak pemanasan global sebesar 2\%. Pengurangan crude protein sebesar $1 \%$ dalam pakan dapat menurunkan ekskresi nitrogen sebesar 10\% (Giannenas et al., 2017). 
Beberapa penelitian lain melakukan substitusi sebagian maupun keseluruhan dari satu atau beberapa bahan pakan yang ternyata memberikan pengaruh positif terhadap lingkungan. Garcia-Launay et al. (2018) melakukan perubahan komposisi pakan di tahap finisher dengan mengganti maize co-products dan protein seeds dengan wheat co-products. Hal yang sama seperti dalam penelitian Arroyo et al. (2013) yang melakukan substitusi jagung dan bungkil kedelai dengan sorgum dan sumber protein lainnya ternyata sangat efisien dalam mengurangi dampak pemanasan global sebesar $17 \%$. Sementara menurut Dekker et al. (2011), mengganti beberapa bahan pakan impor (gandum, bunga matahari, bungkil kedelai) di Belanda dapat menurunkan dampak pemanasan global sebesar $9 \%$ dan penggunaan energi sebesar $21 \%$.

Selain pakan, limbah padat organik berupa litter yang bercampur dengan kotoran ayam (manure) juga dapat meningkatkan emisi $\mathrm{NH}_{3}, \mathrm{~N}_{2} \mathrm{O}$ dan $\mathrm{CH}_{4}$ di peternakan karena manajemen limbah padat organik tersebut (penanganan, penyimpanan dan aplikasinya di lapangan) (Lima et al., 2019). Dalam penelitian González-García et al. (2014), diketahui bahwa manajemen manure memberikan kontribusi sebesar $11 \%$ terhadap dampak pemanasan global, dimana emisi $\mathrm{CH}_{4}$ berkontribusi $4 \%$. Sedangkan menurut Lima et al. (2019), dari total emisi yang dihasilkan dari manajemen manure, kontribusi emisi $\mathrm{CH}_{4}$ $18,9 \%, \mathrm{~N}_{2} \mathrm{O}$ direct $19,3 \%$ dan $\mathrm{N}_{2} \mathrm{O}$ indirect $61,8 \%$. Lima et al. (2019) menambahkan bahwa manajemen manure juga menggunakan energi yang berkontribusi menghasilkan emisi gas rumah kaca berupa $\mathrm{CH}_{4}, \mathrm{~N}_{2} \mathrm{O}$ dan $\mathrm{CO}_{2}$ dari penggunaan bahan bakar diesel serta emisi $\mathrm{CO}_{2}$ dari penggunaan energi listrik. Pengolahan litter yang bercampur dengan kotoran ayam (manure) melalui pengomposan untuk pupuk organik dapat mengurangi penggunaan sejumlah tertentu pupuk sintetis di lahan pertanian karena komposisi N, P dan $\mathrm{K}$ dalam limbah tersebut (Kelleher et al., 2002). Selanjutnya González-García et al. (2014) juga menambahkan bahwa aplikasi manure sebagai pupuk organik memberikan pengaruh positif terhadap lingkungan yang dapat mengurangi dampak lingkungan hingga 4\%. Di sisi lain, manajemen penyimpanan manure yang lebih baik dapat mengurangi emisi $\mathrm{CH}_{4}$ yang dihasilkan (Kalhor et al., 2016).

Penggunaan energi di rumah pemotongan ayam juga ikut berkontribusi terhadap total emisi gas rumah kaca. Konsumsi energi listrik merupakan kontributor utama dalam menghasilkan emisi $\mathrm{CO}_{2}$ di rumah pemotongan ayam (Hafiz et al., 2017). Energi listrik ini digunakan untuk menyalakan mesin dan peralatan produksi, pendingin, lampu penerangan serta untuk pengoperasian instalasi pengolahan air limbah. González-García et al. (2014) dan Hafiz et al. (2017) menyebutkan bahwa energi listrik yang digunakan di rumah pemotongan ayam didominasi oleh keperluan pendingin. Hafiz et al. (2017) menambahkan bahwa energi listrik sebagian besar digunakan untuk mengoperasikan kompresor amonia untuk mendinginkan ruangan pendingin dengan suhu $-4^{\circ} \mathrm{C}$. Penggunaan energi listrik untuk kompresor sebanyak $72 \%$ dari total konsumsi listrik, sehingga dengan mengurangi konsumsi listrik di ruang kompresor akan secara signifikan menurunkan emisi $\mathrm{CO}_{2}$. Rekomendasi perbaikan untuk mengurangi konsumsi listrik adalah dengan mengurangi waktu ketika memasukkan produk ke ruang pendingin serta mengurangi jumlah pintu masuk di ruang pendingin. Kedua alternatif perbaikan tersebut dapat mengurangi konsumsi listrik sebanyak 5\% dengan mengurangi kehilangan panas ke lingkungan. Selain itu, Hafiz et al. (2017) dalam penelitiannya juga melaporkan bahwa melalui pemasangan inverter pada kompresor dapat mengurangi konsumsi listrik sebanyak $10 \%$. Meskipun pemasangan inverter pada kompresor ini membutuhkan biaya investasi di awal, namun dengan manfaat yang bisa diperoleh berupa penghematan listrik dapat mengurangi biaya produksi sekaligus mengurangi jumlah emisi $\mathrm{CO}_{2}$ yang dihasilkan. Pada proses produksi juga dibutuhkan sumber energi panas berupa bahan bakar untuk proses perebusan (scalding) yang sebagian besar menggunakan bahan bakar diesel untuk pembakaran di boiler, yang berkontribusi terhadap peningkatan emisi $\mathrm{CO}_{2}, \mathrm{CH}_{4}$, dan $\mathrm{N}_{2} \mathrm{O}$. Penggunaan bahan bakar alternatif yang lebih ramah lingkungan seperti biodiesel sebagai pengganti bahan bakar fosil dapat mengurangi dampak lingkungan.

\section{Validasi Sistem}

Sistem penilaian daur hidup ayam potong dapat memprediksi dampak lingkungan emisi gas rumah kaca dengan hasil yang mendekati nilai aktualnya. Sistem ini juga dapat menentukan hotspot dengan tepat sebagai acuan untuk merumuskan rekomendasi perbaikan yang sesuai.

\section{Keunggulan dan Keterbatasan Sistem}

Sistem ini memiliki keunggulan yaitu lebih mudah dan cepat karena setiap aktor memasukkan data yang diperlukan melalui sistem atau database inventori, nilai dampak lingkungan dapat terpantau secara real time, nilai dampak lingkungan otomatis berubah ketika ada perubahan data inventori, serta hasil yang diperoleh dapat dibandingkan dengan hasil sebelumnya. Selain itu, sistem ini memiliki keterbatasan yaitu penilaian daur hidup (LCA) masih terbatas pada ruang lingkup cradle-to-gate (proses budidaya, transportasi dan produksi ayam potong) dengan kategori dampak hanya emisi gas rumah kaca.

\section{KESIMPULAN DAN SARAN}

\section{Kesimpulan}


Komponen sistem penilaian daur hidup ayam potong telah teridentifikasi. Sistem penilaian daur hidup ayam potong menghasilkan model yang dapat memprediksi dampak emisi gas rumah kaca sebesar 96,22\% dari nilai aktualnya dan pakan merupakan kontributor terbesar terhadap emisi gas rumah kaca. Alternatif rekomendasi perbaikan berdasarkan hasil penelitian diantaranya peningkatan efisiensi pakan dari segi jumlah, komposisi serta kandungan nutrisi dalam pakan yang dikonsumsi; pemasangan inverter pada kompresor amonia sebagai upaya penghematan listrik; penggunaan bahan bakar ramah lingkungan seperti biodiesel; pemanfaatan limbah litter dan kotoran ayam sebagai pupuk organik yang disertai dengan manajemen penyimpanan manure yang lebih baik.

\section{Saran}

Desain sistem penilaian daur hidup ayam potong perlu dilanjutkan sampai menjadi software perhitungan LCA dengan batasan sistem yang lebih komprehensif yaitu cradle-to-grave (mulai dari proses budidaya, transportasi, produksi, distribusi, penggunaan konsumen hingga pembuangan akhir), serta dengan mengkaji lebih banyak kategori dampak lingkungan seperti eutrofikasi dan asidifikasi.

\section{DAFTAR PUSTAKA}

Anbu P, Hilda A, dan Gopinath SCB. 2004. Keratinophilic fungi of poultry farm and feather dumping soil in Tamil Nadu, India. Mycopathologia. 158 (3): 303-309.

Arroyo J, Fortun-Lamothe L, Auvergne A, Dubois JP, Lavigne F, Bijja M, Aubin J. 2013. Environmental influence of maize substitution by sorghum and diet presentation on goose foie gras production. Journal Cleaner Production. 59: 51-62.

Aziz HA, Puat NNA, Alazaiza MYD, Hung YT. 2018. Poultry slaughterhouse wastewater treatment using submerged fibers in an attached growth sequential batch reactor. International Journal Environ Res Public Health. 15 (8): 112.

[BPS] Badan Pusat Statistik. 2019. Produksi Daging Ayam Ras Pedaging Menurut Provinsi. Jakarta: Badan Pusat Statistik Republik Indonesia.

[BSN] Badan Standarisasi Nasional. 2016. SNI ISO 14040:2016 tentang Manajemen Lingkungan Penilaian Daur Hidup - Prinsip dan Kerangka Kerja (Environmental Management - Life Cycle Assessment - Principles and Framework). Jakarta: Badan Standarisasi Nasional.

Cesari V, Zucali M, Sandrucci A, Tamburini A, Bava L, Toschi I. 2017. Environmental impact assessment of an Italian vertically integrated broiler system through a life cycle approach. Journal Cleaner Production. 143: 904-911.

Dekker SEM, de Boer IJM, Vermeij I, Aarnink AJA,
Koerkamp PWGG. 2011. Ecological and economic evaluation of Dutch egg production systems. Livest Science 139 (1-2): 109-121.

Djatna T. 2020. Analisis dan Desain Sistem Produksi Agroindustri: Pendekatan Digital Business Ecosystem. Bogor: IPB Press.

Fadilah R, Polana A, Alam S, Parwanto E. 2006. Sukses Beternak Ayam Broiler. Jakarta: Agromedia Pustaka.

Garcia-Launay F, Dusart L, Espagnol S, LaisseRedoux S, Gaudré D, Méda B, Wilfart A. 2018. Multiobjective formulation is an effective method to reduce environmental impacts of livestock feeds. Brazilian Journal Nutr. 120 (11): 1298-1309.

Giannenas I, Bonos E, Anestis V, Filioussis G, Papanastasiou DK, Bartzanas T, Papaioannou N, Tzora A, Skoufos I. 2017. Effects of protease addition and replacement of soybean meal by corn gluten meal on the growth of broilers and on the environmental performances of a broiler production system in Greece. PLoS One. 12 (1): $1-26$.

González-García S, Gomez-Fernández Z, Dias AC, Feijoo G, Moreira MT, Arroja L. 2014. Life cycle assessment of broiler chicken production: A Portuguese case study. Journal Cleaner Production. 74: 125-134.

Hafiz MIM, Zulfattah ZM, Munajat NA, Sakinah ABF, Asyraf HM. 2017. Cleaner production implementation at chicken slaughtering plant. ARPN J Eng Appl Sci. 12 (14): 4324-4328.

Han J, Kamber M, dan Pei J. 2012. Data Mining: Concepts and Techniques. $3^{\text {rd }}$ ed. Waltham: Elsevier.

[IPCC] Intergovernmental Panel on Climate Change. 2007. Fourth Assessment Report (AR4). Washington DC (UK): IPCC.

Joshi SG, Tejashwini M., Revati N, Sridevi R, Roma D. 2007. Isolation, identification and characterization of a feather degrading bacterium. International Journal Poult Science. 6 (9): 689-693.

Kalhor T, Rajabipour A, Akram A, Sharifi M. 2016. Environmental impact assessment of chicken meat production using life cycle assessment. Inf Process Agric. 3 (4): 262-271.

Kebreab E, Liedke A, Caro D, Deimling S, Binder M, Finkbeiner M. 2016. Environmental impact of using specialty feed ingredients in swine and poultry production: A life cycle assessment. Journal Animal Science. 94 (6): 2664-2681.

Kelleher B, Leahy J, Henihan A, O’Dwyer T, Sutton D, Leahy M. 2002. Advances in poultry litter disposal technology - A review. Bioresour Technol. 83: 27-36.

Klopffer W, Grahl B. 2014. Life Cycle Assessment (LCA): A Guide to Best Practice. Weinheim: Wiley-VCH.

Kuncoro M. 2014. Metode Riset Untuk Bisnis \& 
Ekonomi: Bagaimana Meneliti dan Menulis Tesis?. $4^{\text {th }}$ ed. Jakarta: Erlangga.

Leinonen I, Kyriazakis I. 2016. How can we improve the environmental sustainability of poultry production?. Proc Nutr Soc. 75 (3): 265-273.

Leinonen I, Williams AG. 2015. Effects of dietary protease on nitrogen emissions from broiler production: A holistic comparison using life cycle assessment. Journal Science Food Agricultur. 95 (15): 3041-3046.

Leinonen I, Williams AG, Wiseman J, Guy J, Kyriazakis I. 2012. Predicting the environmental impacts of chicken systems in the United Kingdom through a life cycle assessment: Broiler production systems. Poult Sci. 91 (1): 8-25.

Lima ND da S, Nääs I de A, Garcia RG, Moura DJ de. 2019. Environmental impact of Brazilian broiler production process: Evaluation using life cycle assessment. Journal Cleaner Production. 237: 117752.

López-Andrés JJ, Aguilar-Lasserre AA, MoralesMendoza LF, Azzaro-Pantel C, Pérez-Gallardo JR, Rico-Contreras JO. 2018. Environmental impact assessment of chicken meat production via an integrated methodology based on LCA, simulation and genetic algorithms. Journal Cleaner Production.. 174: 477-491.

Nurhayati, Marimin, Djatna T, Permana IG. 2016. Kinerja rantai pasok dan nilai tambah dengan internalisasi aspek lingkungan pada agroindustri ayam ras pedaging. Jurnal Teknologi Industri Pertanian. 26 (3): 311-320.
Pelletier N. 2008. Environmental performance in the US broiler poultry sector: Life cycle energy use and greenhouse gas, ozone depleting, acidifying and eutrophying emissions. Agric Syst. 98 (2): 67-73.

Russell SJ, Norvig P. 2010. Artificial Intelligence: A Modern Approach. $3^{\text {rd }}$ ed. New Jersey: Pearson.

Siang JJ. 2005. Jaringan Syaraf Tiruan dan Pemrogramannya Menggunaan Matlab. Yogyakarta: ANDI.

Skunca D, Tomasevic I, Nastasijevic I, Tomovic V, Djekic I. 2018. Life cycle assessment of the chicken meat chain. Journal Cleaner Production. 184: 440-450.

Suffian SA, Sidek AA, Matsuto T, Al Hazza MH, Yusof HM, Hashim AZ. 2018. Greenhouse gas emission of broiler chicken production in Malaysia using life cycle assessment guidelines: A case study. Journal Eng Mater Manuf. 3 (2): 87-97.

Tallentire CW, Mackenzie SG, Kyriazakis I. 2017. Environmental impact trade-offs in diet formulation for broiler production systems in the UK and USA. Agric Syst. 154: 145-156.

Wiedemann SG, McGahan EJ, Murphy CM. 2017. Resource use and environmental impacts from Australian chicken meat production. Journal Cleaner Production.. 140: 675-684.

Zhang X, Liu Y, Yang M, Zhang T, Young AA, Li X. 2013. Comparative study of four time series methods in forecasting typhoid fever incidence in China. PLoS One. 8 (5): e63116. 